\title{
Cyclical release of vasoactive intestinal polypeptide (VIP) from a pancreatic islet cell apudoma
}

\author{
B. L. DEVINE \\ M.B., M.R.C.P. (U.K.) \\ R. I. RUSSELL \\ M.D., Ph.D., F.R.C.P.
}

\author{
H. A. CARMichael \\ M.B., Ch.B., M.R.C.P.
}

S. N. JOFFE

M.D., F.R.C.S.

Glasgow Royal Infirmary

\begin{abstract}
Summary
A patient is described who presented with the classical symptomatology and profound electrolyte disturbance of the Verner-Morrison syndrome due to a pancreatic apudoma secreting vasoactive intestinal polypeptide (VIP). Diagnosis was confirmed by plasma VIP as measured by a radio-immunoassay technique now available. It is suggested that the cyclical nature of the symptoms in this case was due to cyclical release of VIP from the tumour in response to an unknown stimulus. Perfusion studies confirmed the excess secretory state of water, sodium and chloride in the small intestine. Symptoms were completely abolished by surgery and the progress is being monitored by means of serial plasma VIP estimations to detect any early recurrence of metastatic disease.
\end{abstract}

\section{Introduction}

The Verner-Morrison syndrome (Verner and Morrison, 1958) consisting of watery diarrhoea, hypokalaemia and achlorhydria or hypochlorhydria, is now recognized as being frequently associated with non-beta islet cell tumours of the pancreas, although cases have subsequently been described in association with phaeochromocytoma, ganglioneuroblastoma, and bronchial carcinoma (Said and Faloona, 1975). The clinical features of the syndrome result from the hormone-like effect of polypeptides produced by the tumour cells. Vasoactive intestinal polypeptide (VIP) is thought to be the most likely cause of the syndrome (Bloom, Polak and Pearse, 1973) as the pharmacological effects of the hormone correlate well with the clinical symptoms and signs. VIP was first isolated from small intestine of pig in 1970 (Said and Mutt, 1970) and was subsequently synthetized (Bodansky, Klausner and Said, 1973). Biological actions of VIP have been described but its physiological stimulus for release have yet to be discovered. Since the measurement of VIP by radioimmunoassay, elevated plasma levels of VIP have been found in over $95 \%$ of cases presenting with the syndrome (Said and Faloona, 1975).

A patient is now described whose clinical features correlated well with the classical description of the syndrome. It will be shown that the cyclical nature of her symptoms were associated with cyclical release of VIP from tumour cells. Changes in jejunal fluid and electrolytes will be described and the possible value of serial VIP estimations in long-term followup after treatment discussed.

\section{Case report}

A 66-year-old female, presented with a 6-week history of profuse watery diarrhoea, anorexia, vomiting, weight-loss and extreme weakness. During the previous eighteen months similar episodes had been occurring at 6-week intervals, usually preceded by facial flushing. Her only other past history of note was a cholecystectomy for gall stones two years previously. No pancreatic tumour or other intraabdominal abnormality was noted at that operation. Clinical examination revealed only gross dehydration and generalized weakness. Biochemical and haematological investigations were as follows:

$\mathrm{Hb} 13.2 \mathrm{~g} / \mathrm{dl}$; MCV 85; white cell count $16.2 \times$ $10^{9} / 1$; ESR (Westergren) $72 \mathrm{~mm} / \mathrm{hr}$. Plasma: sodium $122 \mathrm{mmol} / 1(\mathrm{~N}=136-144 \mathrm{mmol} / \mathrm{l})$; potassium $1 \cdot 1$ $\mathrm{mmol} / \mathrm{l}(\mathrm{N}=3.4-4.9 \mathrm{mmol} / \mathrm{l})$; chloride $94 \mathrm{mmol} / \mathrm{l}$ ( $\mathrm{N}=95-105 \mathrm{mmol} / \mathrm{l})$; phosphate $0.8 \mathrm{mmol} / 1(\mathrm{~N}=$ $0.8-1.4 \mathrm{mmol} / \mathrm{l})$; alkaline phosphate $732 \mathrm{u} . / 1(\mathrm{~N}=$ $80-280$ u./l). Serum: calcium $2 \cdot 82 \mathrm{mmol} / 1(\mathrm{~N}=2 \cdot 2$ $2.6 \mathrm{mmol} / \mathrm{l}$ ); globulin $29 \mathrm{~g} / \mathrm{l}$ (normal); SGOT $81 \mathrm{u} . / 1$ $(\mathrm{N}=12-48 \mathrm{u} . / \mathrm{l})$; SGPT $110 \mathrm{u} . / \mathrm{l}(\mathrm{N}=8-41 \mathrm{u} . / \mathrm{l})$. Urea $18 \mathrm{mmol} / 1(\mathrm{~N}=2 \cdot 5-7.0 \mathrm{mmol} / \mathrm{l})$ albumin $26 \mathrm{~g} / \mathrm{l}(\mathrm{N}=35-55 \mathrm{gl})$. 
Chest X-ray, barium enema, stool cultures, Widal and Brucella titres were all normal. Sigmoidoscopy showed a normal rectal mucosa with watery stool content. The electrocardiograph showed prominent $\mathrm{U}$ waves consistent with hypokalaemia.

On the first admission she was treated symptomatically with fluid and electrolyte replacement. The diarrhoea settled spontaneously and the plasma biochemistry returned to normal. Over the next 4 months however, the symptoms recurred on four occasions and on each occasion they were associated with hypokalaemia and hypercalcaemia.

The ESR remained elevated at $100 \mathrm{~mm} / \mathrm{hr}$. Further investigations were normal with regard to 5-hydroxyindoleacetic acid (5-HIAA) excretion in the urine, serum and urinary amylase, barium meal, small bowel enema and X-ray of chest. There was no evidence of hyperparathyroidism on X-ray of hands, wrists and pituitary fossa. Screening of urine for Bence-Jones protein was negative. Total faecal bile acids, plasma cortisol and Synacthen test were also normal.

In view of her clinical presentation, and with no evidence of any organic pathology in her gastrointestinal tract, a provisional diagnosis of VernerMorrison syndrome was made. This was confirmed by finding a markedly elevated amount of plasma VIP as measured by radioimmunoassay, which exceeded $600 \mathrm{pg} / \mathrm{ml}(\mathrm{N}=50 \mathrm{pg} / \mathrm{ml})$. This abnormally high level was confirmed by two subsequent estimations. Serial VIP levels were thereafter obtained throughout her stay in hospital and correlated with her clinical condition and plasma biochemistry (Fig. 1). Pentagastrin stimulation test $(6 \mu \mathrm{g} / \mathrm{kg}$ sub- cutaneously) demonstrated achlorhydria. Attempts were made to localize the suspected tumour by means of radio-isotope scan of the liver and spleen, grey-scale ultrasonography of the abdomen and retrograde adrenal venography, with no success.

A pan-aortogram with selective catheterization of the coeliac and superior mesenteric artery demonstrated a tumour in the tail of the pancreas (Fig. 2).

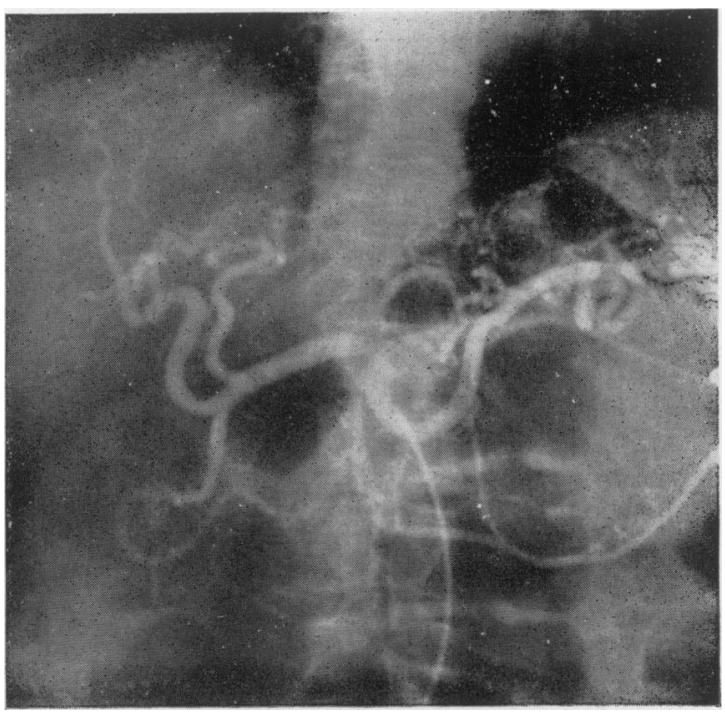

FIG. 2. Coeliac and superior mesenteric artery angiography.

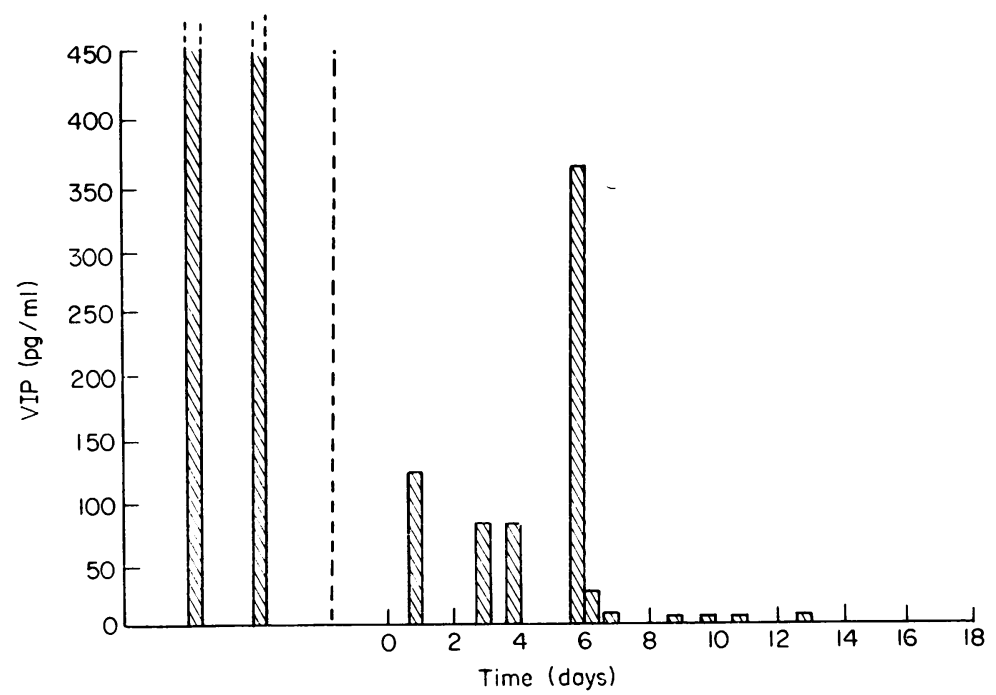

FIG. 1. VIP levels during hospital stay. 
Small intestinal absorption was measured by a perfusion study using a triple lumen tube (Russell et al., 1973). This showed diminished water absorption and a net secretion of sodium and chloride compared with a standard control group studied previously (Table 1). Jejunal aspiration before and after surgery showed marked reduction in jejunal secretion following operation (Table 2).

TABLE 1. Triple lumen jejunal perfusion before surgery

\begin{tabular}{ccc}
\hline $\begin{array}{c}\text { Mean } \\
\text { sodium and water } \\
\text { absorption }\end{array}$ & Patient & $\begin{array}{c}\text { Twelve } \\
\text { patient control series } \\
\text { Mean } \pm \text { s.e. mean }\end{array}$ \\
\hline $\begin{array}{c}\text { Water } \\
(\mathrm{ml} / \mathrm{hr} / 30 \mathrm{~cm})\end{array}$ & 61.4 & $226 \pm 8.2$ \\
$\begin{array}{c}\text { Sodium } \\
(\mathrm{mmol} / \mathrm{hr} / 30 \mathrm{~cm})\end{array}$ & -5.47 & $25.3 \pm 1.8$ \\
\hline
\end{tabular}

At abdominal laparotomy (S.N.J.) a large multilobated tumour measuring $12 \times 10 \times 8 \mathrm{~cm}$ was found in the body and tail of the pancreas. It contained several cystic areas and extended through the transverse mesocolon on the left of the middle colic vessels. The liver and para-aortic nodes appeared free of tumour. Stomach, duodenum, kidneys and adrenals were normal. The tumour was completely excised by performing a distal pancreatectomy and splenectomy. Throughout the operation VIP levels were obtained from portal circulation (Fig. 3). Plasma estimations for other polypeptides (gastrin, secretin, insulin and glucagon) were all normal (Table 3).

Tumour histology showed a pancreatic islet cell apudoma of the D-cell type (Fig. 4) with invasion of local nymph nodes by tumour, but liver biopsy and splenic histology were normal. The postoperative recovery was uneventful and the patient was discharged on the 10th day. There has been no recurrence of diarrhoea. The VIP levels and plasma biochemistry have remained normal and the patient is symptom-free 1 year after operation.

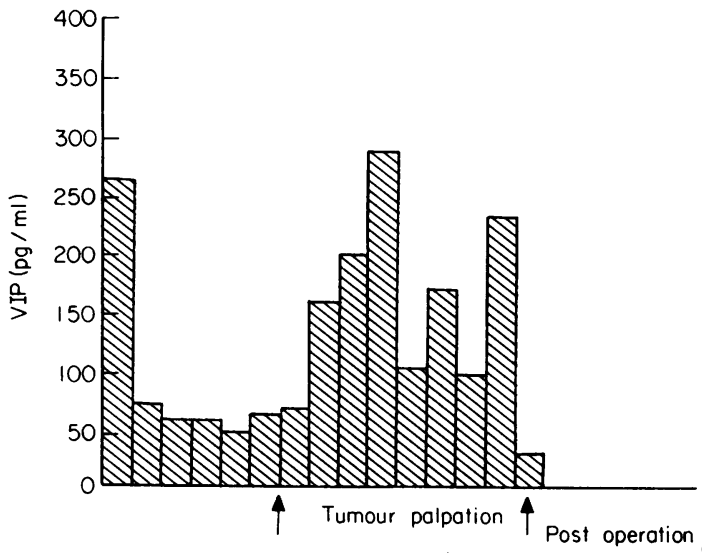

FIG. 3. VIP levels during surgery.

TABle 3. Peptide bioassays

\begin{tabular}{lrl}
\hline Gastrin & $135 \mathrm{pg} / \mathrm{ml}$ & $(\mathrm{N}=0-150 \mathrm{pg} / \mathrm{ml})$ \\
Insulin & $5 \mu \mathrm{u} . / \mathrm{ml}$ & $(\mathrm{N}=0.5-15 \mu \mathrm{u} . / \mathrm{ml})$ \\
Pancreatic glucagon & $70 \mathrm{pg} / \mathrm{ml}$ & $(\mathrm{N}=0-150 \mathrm{pg} / \mathrm{ml})$ \\
Total glucagon & $180 \mathrm{pg} / \mathrm{ml}$ & $(\mathrm{N}=0-120 \mathrm{pg} / \mathrm{ml})$ \\
Secretin & $10 \mathrm{pg} / \mathrm{ml}$ & $(\mathrm{N}=0-100 \mathrm{pg} / \mathrm{ml})$
\end{tabular}

TABLE 2. Jejunal aspiration before and after surgery

\begin{tabular}{lccccc}
\hline & \multicolumn{2}{c}{$\begin{array}{c}\text { Pre-operative } \\
\text { Volume }-54 \mathrm{ml} / 60 \mathrm{~min}\end{array}$} & & \multicolumn{2}{c}{$\begin{array}{c}\text { Postoperative } \\
\text { Volume } 3.9 \mathrm{ml} / 60 \mathrm{~min}\end{array}$} \\
\cline { 2 - 3 } \cline { 5 - 6 } & $\begin{array}{c}\text { Mean concentration } \\
(\mathrm{mmol} / \mathrm{l})\end{array}$ & $\begin{array}{c}\text { Total output } \\
(\mathrm{mmol} / \mathrm{hr})\end{array}$ & & $\begin{array}{c}\text { Mean concentration } \\
(\mathrm{mmol} / \mathrm{l})\end{array}$ & $\begin{array}{c}\text { Total output } \\
(\mathrm{mmol} / \mathrm{hr})\end{array}$ \\
\hline Sodium & 142 & 7.67 & & 159 & 0.6201 \\
Potassium & 5.15 & 0.218 & & 1.95 & 0.0076 \\
$\mathrm{CO}_{2}$ & 32 & 1.856 & & 10 & 0.007 \\
Total 'protein & 2.45 & 0.142 & & 7 & 0.027 \\
Amylase & 49 & 2.842 & & 205.25 & 0.800 \\
\hline
\end{tabular}




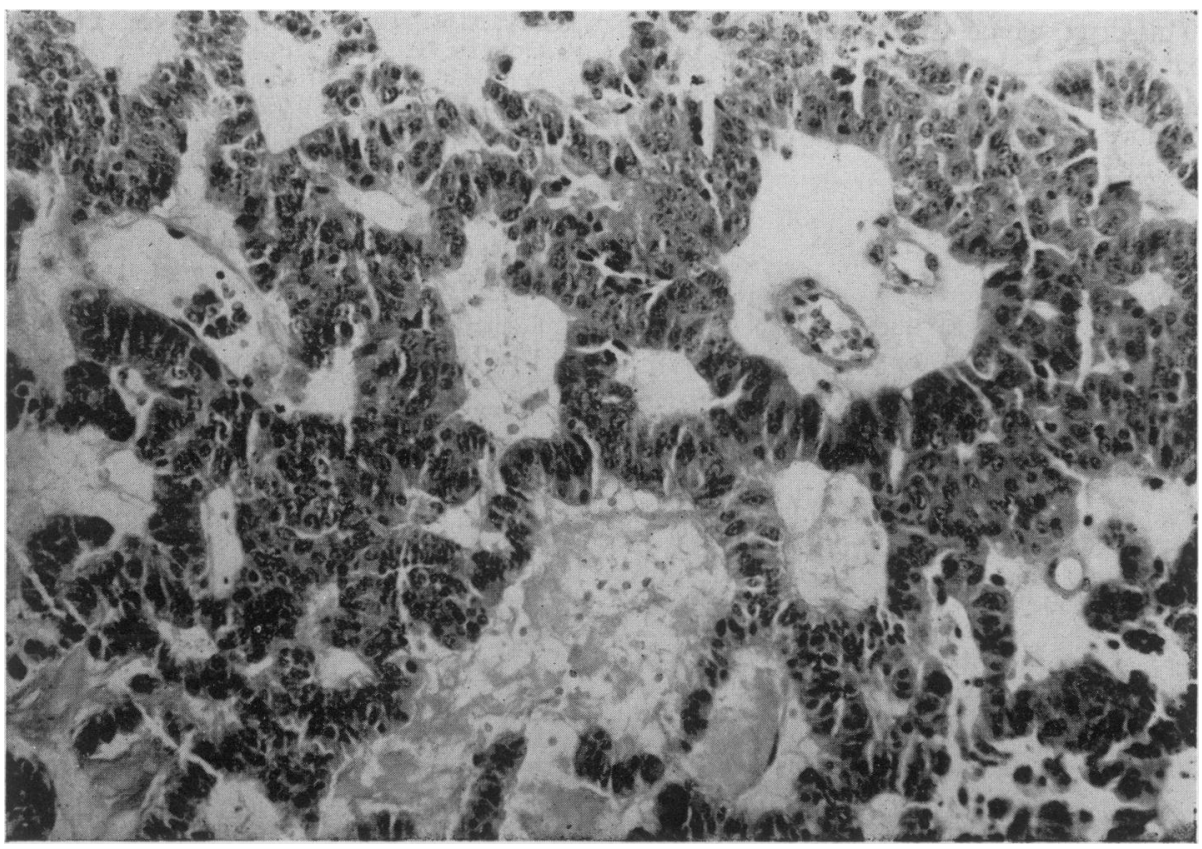

FIG. 4. Section of tumour. (HE, $\times 400$ magnification.)

\section{Discussion}

This patient satisfies the criteria of the VernerMorrison syndrome which include watery diarrhoea, hypokalaemia and achlorhydria or hypochlorhydria. Associated features may include hyperglycaemia and hyperinsulinism, hypercalcaemia, hypotension, flushing, metabolic acidosis and renal failure (Kerins, Said and Vane, 1970). The induced hypokalaemia and dehydration may be severe and life-threatening. Diagnosis is often delayed. In this case, a pancreatic tumour was found and the symptoms were abolished by surgical removal of this tumour.

The cyclical peaks in VIP seen in Fig. 1 showed excellent correlation with recurrence of diarrhoea and weakness. The peak of VIP (Fig. 3) produced during surgery was related to manipulation of the tumour, and caused a profound and immediate fall in the systolic and diastolic pressure of $20 \mathrm{mmHg}$. This tends to confirm the supposition that a vasoactive substance, e.g. VIP, was contained in the tumour, and that cyclical release of this substance in response to an unknown stimulus was responsible for the profuse diarrhoea. The hypothesis is supported by the absence of symptoms in association with very low levels of VIP following surgery, although it is possible that other vasoactive substances such as prostaglandins, which could add to, or even account for the symptoms were also being produced by the tumour.
The striking dehydration, hypokalaemia and hyponatraemia seen in this case were due to the profuse and extremely watery diarrhoea so characteristic of the disease. Both increased small intestinal secretion and diminished absorption of water and electrolytes have been suggested as the mechanism for the fluid loss. It has been shown that VIP stimulates adenylate cyclase and cyclic-AMP in intestinal mucosa in a similar pattern to cholera toxin and prostaglandins, with the production of an intestinal secretion of water and electrolyte (Schwartz et al., 1974). Pancreatic secretion, particularly of bicarbonate rich juice, is also known to occur (Barbezat and Grossman, 1971) and may account for the severe acidosis present during exacerbations. It is noteworthy that the studies of jejunal perfusion and secretion confirm the excessive secretory state of the small bowel. The amount of small gut secretion was significantly diminished following surgery.

Although the Verner-Morrison syndrome presents a diagnostic challenge it gives one of those rare opportunities in oncology whereby the use of a biological marker can be used to monitor the progress of a tumour and the effect of treatment. Serial plasma VIP estimations have been carried out in this case, and it is hoped that any tumour recurrence will be diagnosed at an early stage, before the symptoms of diarrhoea recur. Chemotherapy with streptozotocin would then probably be the treatment 
of choice. This drug, which appears to be a specific islet cell toxin, has been shown to be effective in combination with steroids in controlling the symptoms produced by these tumours even in cases which are inoperable (Kahn et al., 1975).

\section{Acknowledgments}

We wish to thank Professor K. Buchanan and Dr S. R. Bloom for their radioimmunoassay of gut polypeptides; Dr Douglas and Dr L. Baird for clinical assistance.

\section{References}

Barbezat, G.O. \& Grossman, M.I. (1971) Intestinal secretion: Stimulation by peptides. Science, 174, 422.

Bloom, S.R., Polak, J.M. \& Pearse, A.G.E. (1973) Vasoactive intestinal peptide and watery diarrhoea syndrome. Lancet, ii, 14.

Bodansky, M., Klausner, V.S. \& Said, S.I. (1973) Biological activities of synthetic peptides corresponding to fragments and to the entire sequence of vasoactive intestinal peptide. Proceedings of the National Academy of Sciences of the United States of America, 70, 382.
KahN, G.R., LeVy, G.A., Gardner, J.D., Millar, J.V., GoRden, P. \& Schein, P.S. (1975) Pancreatic cholera: Beneficial effects of treatment with streptozotocin. New England Journal of Medicine, 292, 941.

Kerins, C., SAID, S.I. \& VANe, J.R. (1970) Hyperglycaemic and glycogenolytic effects of vasoactive intestinal polypeptide. Proceedings of the Society for Experimental Biology and Medicine, 142, 1014.

Russell, R.I., Allan, J.G., Gerskowitch, V.P. \& Cochran, K.M. (1973) The effect of conjugated and unconjugated bile acids on water and electrolyte absorption in the human jejunum. Clinical Science and Molecular Medicine, $45,301$.

SaID, S.I. \& Faloona, G.R. (1975) Elevated plasma and tissue levels of vasoactive intestinal polypeptide in the watery diarrhea syndrome due to pancreatic, bronchogenic and other tumors. New England Journal of Medicine, 293, 155.

SaID, S.I. \& MuTT, V. (1970) Polypeptide with broad biological activity; isolation from small intestine. Science, 169, 1217.

Schwartz, C.J., Kimberg, D.V., Sheerin, H.E., Field, M. \& SAID, S.I. (1974) Vasoactive intestinal peptide stimulation of adenylate cyclase and active electrolyte secretion in intestinal mucosa. Journal of Clinic 7 Investigation, 54, 536.

Verner, John V. \& Morrison Ashton, B. (1958) Islet cell tumor and a syndrome of refractory water diarrhea and hypokalemia. American Journal of Medicine, 25, 374. 